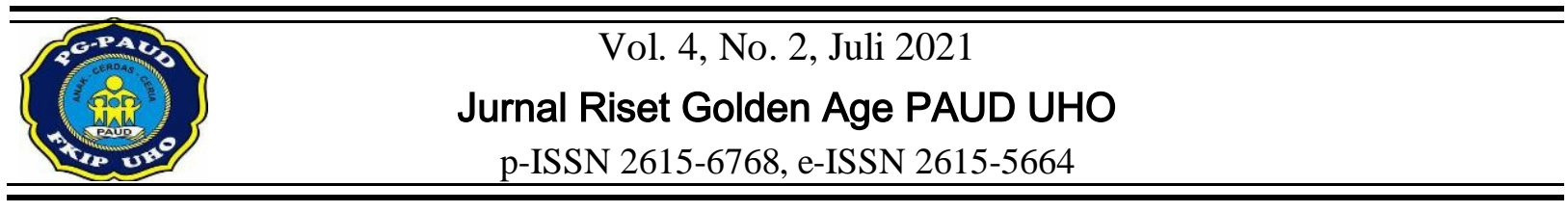

\title{
PENGEMBANGAN MEDIA TEMPEL AKU UNTUK MENINGKATKAN KEMAMPUAN BERPIKIR SIMBOLIK ANAK
}

\author{
Rachmawati $^{1) *}$, Nur Ika Sari Rakhmawati ${ }^{1)}$ \\ ${ }^{1}$ Jurusan PG-PAUD, Universitas Negeri Surabaya. Jln. Lidah Wetan, Surabaya 60213, Indonesia. \\ *Email: rachmawati.17010684058@mhs.unesa.ac.id
}

\begin{abstract}
Abstrak
Penelitian ini bertujuan mengembangkan media Tempel Aku dan menguji kelayakan produk. Metode penelitian menggunakan metode pengembangan desain ADDIE. Langkah-langkah penelitian ini adalah tahap analisis mengkaji tujuan produk yang dikembangkan dan menentukan media yang relevan bagi anak; tahap desain pembuatan media membuat rancangan media, penyusunan materi; tahap pengembangan dilakukan validasi ahli media dan materi; tahap implementasi dilakukan pada usia 5-6 tahun dengan uji terbatas kemudian dilakukan lembar pengamatan oleh 10 orang guru PAUD; tahap evaluasi mengevaluasi tahap analisis sampai tahap implementasi. Subjek uji coba penelitian adalah 5 anak. Instrumen pengumpulan data menggunakan observasi, lembar angket, lembar pengamatan. Validasi pengembangan media menggunakan validasi angket yang dilakukan oleh satu orang ahli media dan materi. Hasil penelitian menunjukkan hasil validasi media sebesar $85 \%$, ahli meteri sebesar $78 \%$ dan pengamatan kepada 10 orang guru sebesar $89 \%$. Berdasarkan hasil tersebut menunjukkan bahwa media Tempel Aku layak digunakan dalam meningkatkan kemampuan berpikir simbolik anak usia 5-6 tahun.
\end{abstract}

Kata kunci: kognitif, media, tempel aku.

\section{DEVELOPMENT OF STICK TO ME MEDIA TO IMPROVE CHILDREN'S SYMBOLIC THINKING ABILITY}

\begin{abstract}
This study aims to develop a media paste me and test the feasibility of the product. The research method uses the ADDIE design development method. The steps of this research are the analysis stage, reviewing the purpose of the product being developed and determining the media that is relevant for children; the design stage of making media making media designs, compiling materials; the development stage is carried out by media and material expert validation; the implementation phase is carried out at the age of 5-6 years with a limited test then observation sheets are carried out by ten PAUD teachers; evaluation stage evaluates the analysis stage to the implementation stage. The subjects of the research trial were 5 children. The data collection instrument used observation, questionnaire sheet, and observation sheet. Validation of media development using questionnaire validation conducted by one media and materials expert. The results showed that the results of media validation were $85 \%$, material experts were $78 \%$ and observations of 10 teachers were $89 \%$. Based on these results, it shows that Tempel Aku media is suitable to be used in improving the symbolic thinking skills of children aged 5-6 years.
\end{abstract}

Keywords: cognitive, media, stick to me.

\section{PENDAHULUAN}

Pendidikan anak usia dini sudah didapat ketika anak belum lahir sampai anak berusia 6 tahun. Menurut (Mertayasa \& Sudarsana, 2018) bahwa pendidikan memberikan rangsangan untuk membantu pertumbuhan dan perkembangan jasmani rohani agar memiliki kesiapan untuk memasuki pendidikan selanjutnya. Pendidikan di TPA, Playgroup dan TK merupakan pendidikan yang memiliki kemampuan karakteristik guna pertumbuhan dan perkembangan anak. Pada tahap ini, (Hamidah, 2020) berpendapat pertumbuhan dan perkembangan anak pasti terpenuhi, jika kegiatan pembelajaran anak mampu 
menstimulasi perkembangan aspek anak. Dari dua pendapat diatas bahwa pendidikan mampu membantu memberikan rangsangan perkembangan dan pertumbuhan bagi anak untuk menstimulasi pembelajaran anak. Oleh karena itu, perkembangan dan pertumbuhan pada pembelajaran dapat difokuskan pada kemampuan kognitif.

Perkembangan kognitif adalah belajar yang melibatkan pengetahuan tentang fakta pemahaman, penerapan, analisis, dan penilaian (Thobroni \& Mumtaz, 2011). Menurut (Sholihah \& Rakhmawati, 2019) mengatakan bahwa perkembangan kognitif adalah suatu proses atau cara berpikir, yakni meliputi kemampuan individu untuk menghubungkan, mempertimbangkan, dan menilai sesuatu yang baik dari kejadian maupun peristiwa yang terjadi. Menurut (Kartika \& Fitri, 2018) mengatakan perkembangan kemampuan kognitif anak sangat diperlukan untuk mengembangkan ilmu pengetahuan anak agar anak bisa melihat, meraba, mendengar melalui panca indra yang dimiliki. Proses ini mempelajari anak untuk berpikir dengan mematuhi peraturan permainan yang dirancang oleh guru agar anak bisa memiliki pengetahuan melalui proses panca indra yang dimilikinya.

Hal ini perkembangan kognitif difokuskan pada salah satu lingkup perkembangan berpikir simbolik. Menurut (Aprilianti \& Fitri, 2019) bahwa kemampuan perkembangan berpikir simbolik dapat mempresentasikan meliputi kemampuan mengenai konsep angka, mengenali benda-benda serta mampu menggunakan berbagai bentuk yang diketahui oleh anak dan juga menumbuhkan kecerdasan yang disebut dengan kecerdasan logis matematika. Menurut (Lestari \& Prima, 2019) aspek perkembangan simbolik adalah bagian terpenting untuk membentuk perilaku pada anak dengan ini pemikiran yang terjadi akan lebih signifikan dalam penggunaan pemahaman dan akan lebih berkembang ketika mereka tumbuh. Salah satu cara untuk mengembangkan kemampuan anak usia dini dalam berpikir simbolik melalui penyediaan pengalaman yang memerlukan strategi berbeda-beda dari masalah satu ke masalah lain. Kemampuan anak ketika menghadapi masalah sangat berkaitan dengan tingkat perkembangan mereka.

Peraturan menteri pendidikan dan kebudayaan republik Indonesia Nomor 137 Tahun 2014 tentang Standar PAUD pada Standar Tingkat Pencapaian Perkembangan Anak (STTPA) lingkup perkembangan kognitif tentang berpikir simbolik anak usia 5-6 tahun yaitu menyebutkan lambang bilangan 1-10, menggunakan lambang bilangan untuk menghitung, mencocokkan bilangan dengan lambang bilangan, mengenal berbagai macam lambang hurus vokal dan kosonan, merepresentasikan berbagai macam benda dalam bentuk gambar atau tulisan (ada benda pensil yang diikuti tulisan dan gambar pensil).

Pada saat dilakukan pengamatan pertama di Banyu Urip berjumlah lima orang pada kelompok B pada bulan November tahun 2020, peneliti menemukan ada beberapa permasalahan. Salah satunya pada permainan maze, anak masih perlu bimbingan orangtua ketika anak bermain. Sebagian besar anak masih melakukan kesalahan dalam memecahkan masalah sederhana, seperti ketika anak diberi tugas untuk menyusun, menyamakan bentuk dan huruf anak cenderung meminta bantuan. Karna bagi anak yang belum paham terhadap perkembangan kemampuan mencocokan akan lebih susah dalam berpikir simbolik untuk anak. Kemampuan anak yang belum mampu menunjukkan sikap kreatif maupun berpikir kognitif, disitulah anak belum bisa menghadapi permasalahan sendiri seperti halnya ketika disuruh mengambil bagian geometri pada jajar genjang anak cenderung melihat temanya atau gurunya sebagai acuan untuk mengetahui bagian mana yang harus diambil terlebih dahulu.

Salah satu penyebab kesulitan yang terjadi dalam berpikir simbolik adalah anak masih belum paham tentang bentuk-bentuk geometri karna kurangnya kemampuan awal yang dimilikinya. Hal ini sejalan dengan (Ningrum \& Chusna, 2019) yang mengatakan bahwa pada saat dilakukan kegiatan pembelajaran dengan mengenalkan geometri terjadi permasalahan kegiatan anak dalam pemanfaatan media khususnya untuk mengenalkan bentuk geometri masih jarang digunakan hal ini dapat memengaruhi proses pembelajaran matematika.

Pembelajaran mengenal geometri merupakan salah satu perkembangan kognitif yang dapat mengenali bentuk lingkaran, segitiga, persegi, dan persegi panjang dan dapat dipelajari untuk membedakan bentuk, menggolongkan benda sesuai ukuran dan bentuknya (Malichah \& Rakhmawati, 2018). Hal ini disebabkan karna pembelajaran hanya dilakukan via WhatsApp dan fasilitas sekolah yang kurang memadai dalam memberikan pelayanan untuk anak. Dari hal tersebut perlu adanya komunikasi bimbingan terhadap guru 
dan orang tua ketika anak belajar. Dengan ini perlu adanya pembelajaran yang menyenangkan yaitu belajar sambil bermain.

Permainan adalah salah satu alat penting bagi anak usia dini dalam mengembangkan aspek kognitif, agar anak dapat meningkatkan kemampuan yang dimilikinya dengan bentuk keterampilan pengetahuan dan cara memainkan game tersebut (Islamiyah, Setiawati, \& Utami, 2020). Permainan ini dibuat dengan menggunakan maze sehingga anak-anak harus melewati maze tersebut dengan berbagai tantangan yang ada. Menurut (Swaboda, Meder, \& Ruggeri, 2020) mengatakan bahwa kemampuan anak secara fleksibel dapat menggolongkan suatu objek berdasarkan fitur alternatif untuk memprediksi seberapa besar anak memainkan permainan. Berdasarkan beberapa pendapat tersebut, maka permainan dapat didefinisikan sebagai usaha keterampilan pengetahuan pada permainan maze untuk menemukan jalan keluar yang tersulit agar mencapai tujuan yang dicapainya. Maka permasalahan yang terjadi dapat diselesaikan salah satunya dengan menggunakan media. Media dapat menyalurkan pesan sehingga penerima bisa menerima pesan dari pengirim.

Media adalah pengantar atau perantara yang menyalurkan pesan untuk ke pengirim ke penerima pesan (Jalinus \& Ambiyar, 2016). Hal ini sejalan dengan (Mashuri, 2019) yang berpendapat bahwa media pembelajaran adalah segala sesuatu yang digunakan untuk kegiatan belajar dan berfungsi sebagai perantara untuk menyalurkan pesan dan informasi agar dapat merangsang cara berpikir siswa, minat, perasaaan dan perhatian siswa sehingga proses interaksi ini dapat berlangsung secara tepat antara guru dan siswa. Menurut (Kustandi \& Darmawan, 2020) mengatakan media adalah wadah pesan yang sumbernya akan diteruskan kepada penerima pesan. Sementara itu, menurut (Dewi \& Nia, 2018) berpendapat bahwa konsep dasar media pembelajaran adalah suatu sumber belajar yang memanfaatkan pengajar untuk menyampaikan informasi, pesan, materi anak agar terjadi interaksi pembelajaran yang optimal. Berdasarkan pendapat tersebut bahwa media pembelajaran adalah alat yang dapat membantu proses anak belajar mengajar, memberikan intruksi, berfungsi menyampaikan pesan, adanya peranan megajar yang dilakukan dilingkungan belajar anak. Media pembelajaran juga untuk sarana dalam meningkatkan kegiatan proses belajar mengajar.
Penelitian yang dilakukan oleh (Ulandari, Hukmi, \& Febrialismanto, 2020) menyimpulkan bahwa media maze trap game dapat meningkatkan kemampuan motorik halus. Penelitian (Narni, \& Salwiah, 2020) mengungkapkan bahwa melalui kegiatan mencocokkan gambar dapat meningkatkan kemampuan kognitif anak. Penelitian (Fitri \& Ibrahim, 2019) mengungkapkan kemampuan visual spasial dapat meningkatkan kegiatan bermain bongkar pasang puzzle logika. Berdasarkan beberapa pendapat tersebut, bahwa permainan puzzle atau maze bila ditingkatkan dengan kemampuan perkembangan berbeda hasilnya dapat meningkatkan permainan tersebut. Akan tetapi dalam penelitian ini yang akan dikembangkan adalah media Tempel Aku dalam meningkatkan kemampuan kognitif berpikir simbolik. Pengembangan media ini yaitu anak dapat belajar menggunakan lambang bilangan, mencocokkan bilangan, mengenal berbagai macam lambang huruf vokal dan kosonan, mempresentasikan berbagai macam benda dalm bentuk gambar dan tulisan sehingga pembelajaran dapat berlangsung menyenangkan bagi anak melalui media tempel aku.

Media tempel aku ini mengembangkan perkembangan aspek kognitif perkembanan aspek berpikir simbolik dengan memiliki keunggulan yang dapat membangkitkan semangat belajar anak. Media ini menggunakan desain dari bahan banner vinly dengan menggunakan aplikasi Corel Draw yang memiliki ukuran $250 \mathrm{~cm}$ x $250 \mathrm{~cm}$. Media Tempel Aku juga dilengkapi dengan bentuk geometri yang terdiri dari 3 macam bentuk yang pertama ada bentuk jajar genjang berukuran 10 $\mathrm{cm} \times 19 \mathrm{~cm}$. Kedua persegi yang berukuran 17 $\mathrm{cm} \times 17 \mathrm{~cm}$, dan yang ketiga segitiga yang berukuran $19 \mathrm{~cm} \times 17 \mathrm{~cm}$. Media geometri ini menggunakan art paper dan dicetak seperti buku. Bentuk geometri ini digunakan untuk menempel di batok kelapa.

Media ini menggunakan bahan batok kelapa untuk berjalan menuju bentuk geometri. Media batok kelapa ini diberi magnet untuk menaruh bentuk geometri. Pada tahap ini juga proses melangkah yang digunakan adalah bentuk geometri bentuk lingkaran yang berukuran $35 \mathrm{~cm}$ x $35 \mathrm{~cm}$ dan memiliki jarak antara lingkaran satu ke lingkaran berikutnya dengan jarak $7 \mathrm{~cm}$. Terakhir geometri lingkaran besar yang berada ditengah digunakan untuk menempel 3 bentuk geometri dan menggunakan bahan art paper dengan warna yang dihasilkan adalah warna biru. Pengembangan media 
Tempel Aku diharapkan dapat membantu perkembangan kognitif berpikir simbolik. Berikut prototype yang akan dibuat dalam pengembangan media penelitian ini.

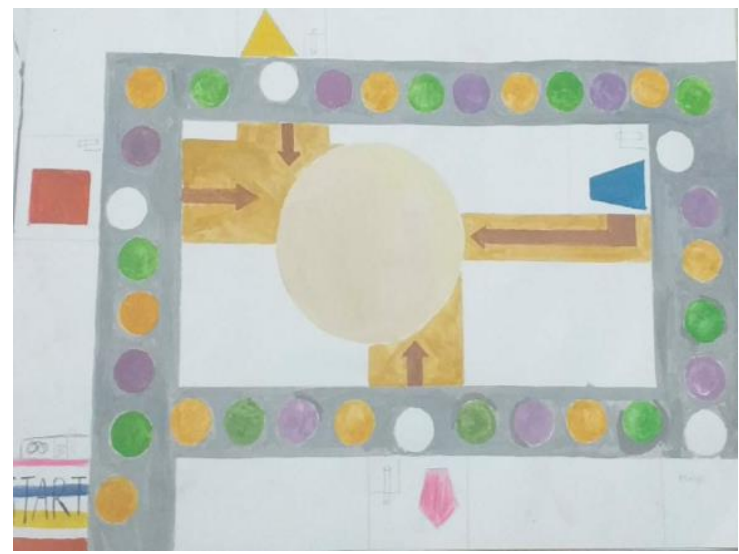

Gambar 1. Prototype Media Tempel Aku

Berdasarkan latar belakang yang telah dipaparkan, maka tujuan penelitian untuk mengetahui desain media tempel aku dalam meningkatkan kemampuan kognitif berpikir simbolik masalah usia 5-6 tahun dan untuk mengetahui kelayakan desain media tempel aku dalam meningkatkan kemampuan kognitif berpikir simbolik usia 5-6 tahun.

\section{METODE}

Metode penelitian yang digunakan dalam penelitian ini yaitu metode penelitian pengembangan atau Research and Development dengan desain ADDIE. Model ADDIE ini terdiri dari beberapa tahap desain, yaitu (analysis, design, development, implementation, evaluation) yang didaptasi oleh Branch (Setyosari, 2020). Namun, pada penelitian ini hanya dibatasi sampai uji coba terbatas. Bagan dari tahapan ADDIE tampak pada Gambar 2.

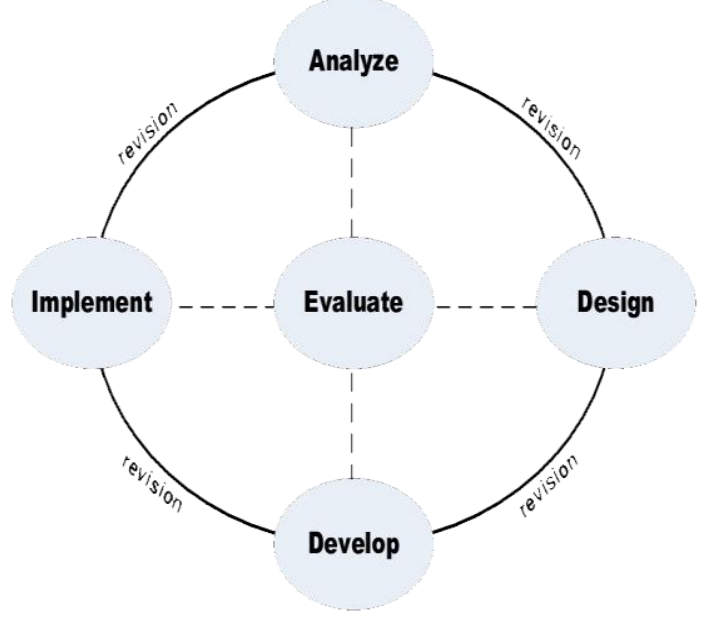

Gambar 2. Tahap Pengembangan Model ADDIE
Tahap analisis kebutuhan untuk mengkaji tujuan dari produk yang akan dikembangkan dengan mengumpulkan data dan informasi. Dalam tahap ini peneliti melakukan observasi dan wawancara. Tahap ini diambil saat peneliti mewawancarai guru pada saat melakukan pembelajaran daring dengan permasalahan anak yang tidak dapat bermain outdoor dan juga untuk mengetahui permasalahan yang terjadi pada kemampuan kognitif dalam berpikir simbolik. Selain itu, dari hasil analisis peneliti menentukan materi pembelajaran media yang relevan untuk dikembangkan dalam media yaitu pengembangan media Tempel Aku untuk anak usia 5-6 tahun.

Kedua tahap desain dalam penelitian ini adalah perancangan pembuatan media melalui corel draw, yang dilengkapi dengan petunjuk langkah-langkah, batok kelapa sebagai alat untuk memainkan, kartu geometri. Media ini diberi nama Tempel Aku yang didalamnya terdapat bentuk geometri, angka, tulisan dan difokuskan pada kemampuan kognitif berpikir simbolik. Selain itu, peneliti juga menyusun instrument angket uji pengguna untuk 10 guru PAUD dan uji coba pengguna kedua anak usia 5-6 tahun berjumlah 5 anak; instrument angket validasi ahli materi dan ahli media.

Ketiga tahap pengembangan dalam penelitian ini dilakukan tahap formatif yaitu tahap pertama. Pada tahap ini dilakukan perancangan media Tempel Aku dengan menggunakan hasil berupa check list yang meliputi validasi dan uji coba pengguna. Pada tahap validasi ahli adalah 1 orang ahli media pembelajaran PAUD dan ahli materi pembelajaran PAUD dengan menggunakan instrument angket. Uji coba pengguna adalah 5 orang anak dan 10 orang Guru PAUD dengan menggunakan hasil pengamatan untuk menilai kemenarikan produk, kemudahan media, kejelasan dari panduan media.

Keempat tahap implementasi dilakukan dengan tahap sumatif untuk menguji keefektifan. Namun tidak bisa dilakukan karena keadaan dan akan dilakukan pada peneliti selanjutnya. Terakhir tahap evaluasi melakukan evaluasi dari tahap 1 sampai tahap 4. Pada tahap analisis dilakukan pengumpulan data dan informasi dengan tahap observasi, yang digunakan untuk menentukan media. Tahap desain dilakukan penilaian pada spesifikasi produk dan bahan penyerta. Pada tahap ini, pengembangan melakukan evaluasi formatif. Evaluasi formatif dilakukan untuk mengetahui validasi dan uji coba pengguna yang digunakan 
untuk mengetahui penyempurnaan. Sedangkan tahap implementasi dilakukan evaluasi untuk uji keefektifan. Namun belum bisa dilakukan, akan dilakukan pada pada penelitian selanjutnya.

Subjek uji coba pengguna dalam penelitian ini adalah anak kelompok B yang berusia 5-6 tahun dilakukan sebanyak 5 orang anak, di wilayah Surabaya tepatnya di Jalan Banyu Urip Wetan dan uji pengguna kepada 10 orang guru PAUD. Penelitian ini menggunakan uji pengguna sebagai penilaian dari praktisnya produk. Selanjutnya ahli materi dan ahli media dibutuhkan menguji kelayakan desain produk pengembangan media Tempel Aku. Pada tahap uji kelayakan dilakukan pada tahap validasi.

Instrumen yang digunakan dalam penelitian ini adalah observasi yang dilakukan oleh anak usia 5-6 tahun di Banyu Urip, observasi digunakan untuk mengetahui sejauh mana desain dan kelayakan media Tempel Aku dalam meningkatkan kemampuan berpikir simbolik anak usia 5-6 tahun, sumber informasi guru dan dosen, dan lembar angket yang terdiri dari ahli media dan ahli materi.

Instrumen angket dari uji pengguna pertama menggunakan 10 orang guru PAUD untuk mengetahui keefektifan media kemenarikan warna, kemenarikan gambar, kejelasan gambar media, kejelasan tulisan angka, kemudahan memainkan maze, kemudahan belajar geometri, kemudahan mepresentasikan berbagai macam benda dalam bentuk gambar dan tulisan kemenarikan keseluruhan media Tempel Aku. Instrumen angket dari validasi ahli media berisi antara lain pengembangan media tempel aku antara lain kesusaian pemilihan bahan menggunakan bahan vinly, kesesuaian pemilihan alat menggunakan batok kelapa, kesesuai kartu geometri, kemenarikan desain, kemenarikan kombinasi warna, keamanan alat dan bahan yang digunakan, keamanan ukuran tulisan.

Instrumen angket dari ahli materi berisi media tempel aku berfungsi sebagai media pembelajaran yang menarik bagi anak, media tempel aku berfungsi untuk mengenalkan konsep perkembangan berpikir simbolik, media tempel aku dapatmenggunakan lambang bilangan untuk menghitung, mencocokkan bilangan dengan lambang bilangan, dan dapat merepresentasikan berbagai macam benda dalam bentuk tulisan..

Teknik analisis data yang digunakan pada penelitian ini adalah kuantitatif. Teknik kuantitatif dalam penelitian ini berupa teknik analisis deskritif untuk menganalisis data validasi angket. Hasil dari data yang digunakan berupa checklist. Lembar angket ini diberikan pada ahli media dan materi serta pada uji coba pengguna pertama. Teknik analisis data dari validasi menggunakan skala Likert seperti pada Tabel 1.

Tabel 1. Presentasi Kriteria Hasil Validasi

\begin{tabular}{cc}
\hline Skor & Penilaian \\
\hline 5 & Sangat baik \\
\hline 4 & Baik \\
\hline 3 & Cukup baik \\
\hline 2 & Kurang baik \\
\hline 1 & Sangat kurang baik \\
\hline & (Mufarrohah \& Rukmi, 2020)
\end{tabular}

Untuk mengetahui data hasil validasi materi dan validasi media menggunakan rumus berikut.

$$
\mathrm{P}=\frac{\Sigma \mathrm{R}}{N} x 100 \%
$$

Dengan $\mathrm{P}=$ Nilai akhir; $\Sigma \mathrm{R}=$ Jumlah skor hasil penilaian; $\mathrm{N}=$ Jumlah skor maksimal. Selanjutnya berdasarkan nilai yang diperoleh dapat diketahui kualitas media dengan kriteria berikut.

Tabel 2. Presentasi Validasi Ahli Media dan Materi

\begin{tabular}{ll}
\hline \multicolumn{1}{c}{ Kriteria } & \multicolumn{1}{c}{ Keputusan } \\
\hline $75 \leq \mathrm{P} \leq 100$ & Valid tanpa revisi \\
\hline $50 \leq \mathrm{P} \leq 75$ & Valid dengan sedikit revisi \\
\hline $25 \leq \mathrm{P} \leq 50$ & $\begin{array}{l}\text { Belum valid dengan banyak } \\
\text { revisi }\end{array}$ \\
\hline $\mathrm{P}<25$ & Tidak valid \\
\hline \multicolumn{1}{c}{ (Mufarrohah \& Rukmi, 2020) }
\end{tabular}

Data hasil angket uji kelayakan dapat digunakan menggunakan penilaian skala Guttman yang tersaji pada Tabel 3.

Tabel 3. Presentasi Kriteria Hasil Uji Pengguna

\begin{tabular}{cc}
\hline Jawaban & Skor \\
\hline Ya & 1 \\
\hline Tidak & 0 \\
\hline \multicolumn{2}{c}{ (Mufarrohah \& Rukmi, 2020) }
\end{tabular}

Data hasil angket diubah menjadi data kuantitatif dengan menggunakan rumus berikut:

$$
\mathrm{P}=\frac{\Sigma \mathrm{R}}{N} x 100 \%
$$

Dengan $\mathrm{P}=$ Nilai akhir; $\Sigma \mathrm{R}=$ Jumlah skor hasil penilaian; $\mathrm{N}=$ Jumlah skor maksimal. Selanjutnya, berdasarkan hasil perhitungan 
dapat diketahui nilai kepraktisan media dengan kriteria berikut ini.

Tabel 4. Presentasi Kriteria Kepraktisan Uji Pengguna

\begin{tabular}{cc}
\hline $\begin{array}{c}\text { Skor Presentasi } \\
(\boldsymbol{\%})\end{array}$ & Kategori \\
\hline $81 \%-100 \%$ & Sangat Praktis \\
\hline $61 \%-80 \%$ & Praktis \\
\hline $41 \%-60 \%$ & Cukup Praktis \\
\hline $21 \%-40 \%$ & Kurang Praktis \\
\hline $0 \%-20 \%$ & Tidak Praktis \\
\hline & (Mufarrohah \& Rukmi, 2020)
\end{tabular}

\section{HASIL DAN PEMBAHASAN}

Penelitian ini menghasilkan sebuah produk media pembelajaran Tempel Aku yang dapat meningkatkan kemampuan kognitif berpikir simbolik anak usia 5-6 tahun. Media pembelajaran ini berhasil dikembangkan sesuai dengan rancangan pembelajaran, yakni sebagai bahan yang dapat memotivasi anak untuk belajar, menyalurkan pesan yang ada di media Tempel Aku dengan cara meningkatkan perkembangan kemampuan kognitif berpikir simbolik, membantu merangsang pikiran anak saat bermain. Hal tersebut sejalan dengan (Hamid, 2020) yang mengatakan bahwa media pembelajaran adalah informasi yang bisa menyalurkan pesan, menerima pesan, bahkan membantu merangsang pikiran anak, perhatian anak, perasaan dan kemauan anak sehingga anak dapat terdorong dalam belajar.

Berdasarkan hasil penelitian ini maka tahapan penelitian mengacu pada model pengembangan ADDIE yang terdiri atas 5 tahapan yaitu analisis, perancangan, pengembangan, implementasi, dan evaluasi.

\section{Analysis (Analisis)}

Tahap pertama yang dilakukan adalah tahap analisis. Pada tahap ini dilakukan identifikasi permasalahan yang terjadi ketika peneliti mengumpulkan data dan informasi. Data diambil pada saat melakukan wawancara pembelajaran daring kepada guru TK Kelompok $\mathrm{B}$ dengan permasalahan anak yang tidak dapat bermain outdoor dengan teman-temanya karna pandemi Covid-19, dan anak mengalami kesulitan belajar khusunya mengenai kemampuan berpikir simbolik yakni tentang bentuk-bentuk geometri, anak belum mampu membaca, anak belum bisa menyusun karna pembelajaran saat ini dilakukan secara online. Berdasarkan tahap analisis ini, peneliti menemukan permasalahan yang dialami oleh 5 orang anak yang menginginkan pembelajaran tatap muka dilakukan karna pembelajaran daring membuat anak bosan dan mereka juga menginginkan pembelajaran yang dilakukan di outdoor. Peneliti juga menemukan permasalahan yang dialami oleh 4 orang anak yakni ketika anak ditanya oleh ibu guru tentang geometri 2 orang anak tidak bisa menjawab dan 2 orang lainnya menjawab dengan jawaban salah. Selain itu ada permasalahan yang membuat perkembangan kognitif berpikir simbolik terganggu, yakni permasalahan yang dialami oleh semua siswa karna pembelajaran dilakukan secara daring membuat anak tidak bisa mendengarkan dengan benar ketika guru membacakan soal atau pertanyaan yang akan disampaikan kepada siswa.

Hasil yang diperoleh pada tahap analisis adalah peneliti mengembangkan suatu media pembelajaran yang layak digunakan dan diharapkan dapat menarik minat belajar anak untuk menerima pesan yang disampaikan, memiliki kemauan dalam belajar dengan mempelajari media Tempel Aku. Dengan demikian, pengumpulan data pada tahap ini peneliti ini mengembangkan media Tempel Aku dalam meningkatkan kemampuan kognitif berpikir simbolik anak usia 5-6 tahun agar dapat membantu dan memenuhi kebutuhan anak usia dini.

\section{Design (Perancangan)}

Tahap perancangan dimulai dengan penentuan materi dengan menggunakan lingkup perkembangan kognitif berpikir simbolik. Pada tahap ini tujuan pembelajaran yang dihasilkan menggunakan lambang bilangan untuk menghitung, mencocokkan bilangan dengan lambang bilangan, merepresentasikan berbagai macam benda dalam bentuk gambar atau tulisan (ada benda yang diikuti tulisan dan gambar). Di tahap perancangan peneliti juga merancang media. Rancangan pembuatan media ini dibuat dengan aplikasi corel draw. Pada tahap ini peneliti menyusun langkah-langkah permainan, kartu geometri yang akan diletakkan dialas permainan, dan buku panduan.

Hasil dari rancangan menghasilkan media yaitu media Tempel Aku memiliki keunggulan yang dapat membangkitkan semangat belajar anak. Media ini didesain menggunakan banner dengan menggunakan aplikasi corel draw. Media ini memiliki ukuran $250 \mathrm{~cm}$ x $250 \mathrm{~cm}$. 


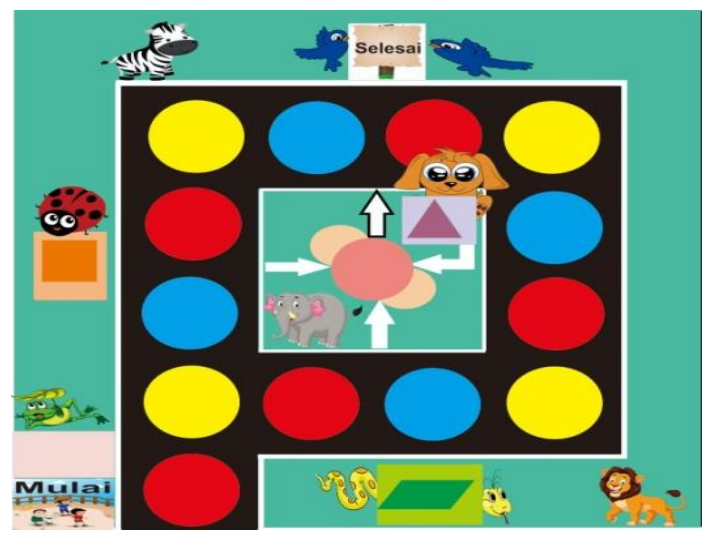

Gambar 3. Desain Alas Media Tempel Aku

Pada Gambar 3 merupakan desain alas media Tempel Aku yang dimana ini terdapat langkah-langkah petunjuk yang akan digunakan saat bermain. Langkah-langkah ini bertujuan agar anak dapat mempresentasikan berbagai macam bentuk tulisan. Kertas yang digunakan adalah kertas art paper yang berukuran A6.

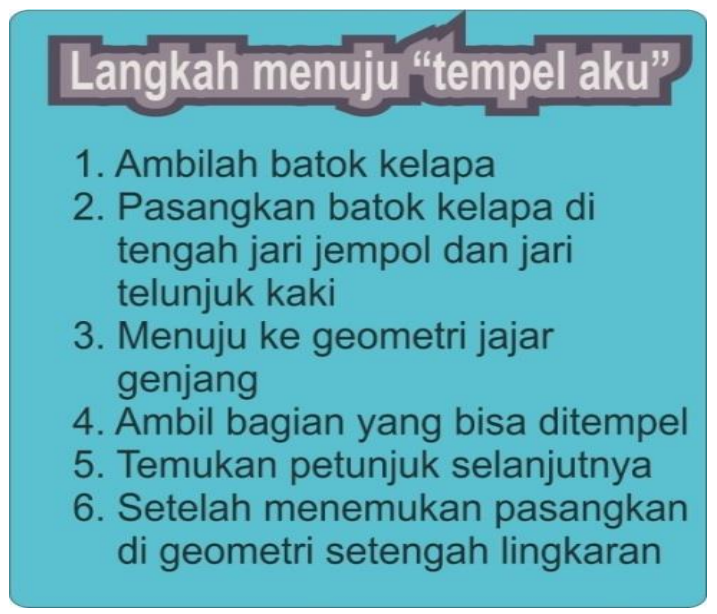

Gambar 4. Petunjuk Media Tempel Aku

Media Tempel Aku juga dilengkapi dengan geometri yang terdiri dari 3 macam bentuk yang pertama ada bentuk jajar genjang, yang berukuran $10 \mathrm{~cm} \times 19 \mathrm{~cm}$. Kedua persegi yang berukuran $17 \mathrm{~cm} \times 17 \mathrm{~cm}$, dan ketiga segitiga yang berukuran $19 \mathrm{~cm} \times 17 \mathrm{~cm}$. Di bagian ini warna yang dihasilkan adalah warna sekunder terdiri dari warna hijau, orange, ungu. Menurut (Wahdini \& Fitri, 2017) bahwa dalam mengenal konsep warna dapat dilakukan dengan cara bermain yang menyenangkan serta melibatkan anak untuk bereksplorasi secara langsung dengan cara ini bermain untuk anak akan sangat mudah dilakukan untuk memahami dan mempelajari konsep warna secara utuh. Dengan ini media Tempel Aku dalam mengenalkan bentuk geometri dan warna di desain berbentuk seperti buku dengan menggunakan bahan art paper agar mudah dilakukan untuk memahami dan mempelajari konsep geomteri dan warna ketika bermain. Media ini bertujuan mengenalkan kemampuan simbolik pada anak. Media ini digunakan untuk menempel di batok kelapa dengan memiliki ukuran $5 \mathrm{~cm}$.

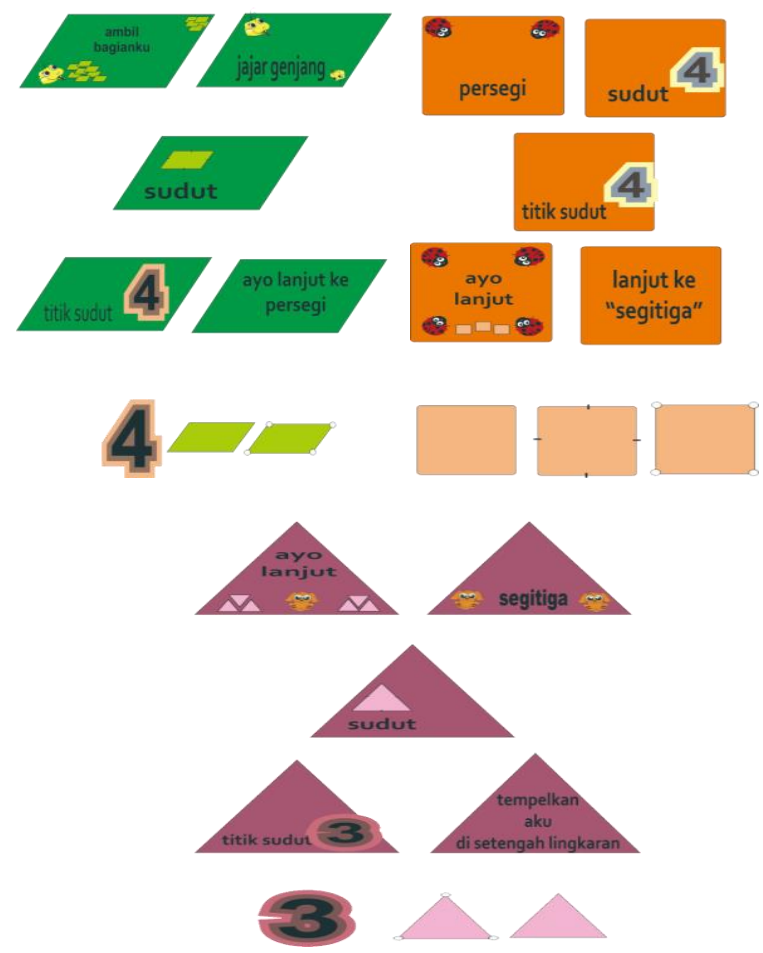

Gambar 5. Desain Geometri 3 Bentuk

Langkah terakhir dalam memainkan media tempel aku terletak pada geometri setengah lingkaran menggunakan bahan art paper yang memiliki ukuran $19 \mathrm{~cm} \times 10 \mathrm{~cm}$ dengan warna yang dihasilkan adalah warna biru dan abu-abu. Media ini digunakan anak untuk mencocokkan hasil dari 3 buku bentuk geometri. Pengembangan media tempel aku diharapkan dapat membantu dalam berpikir simbolik.

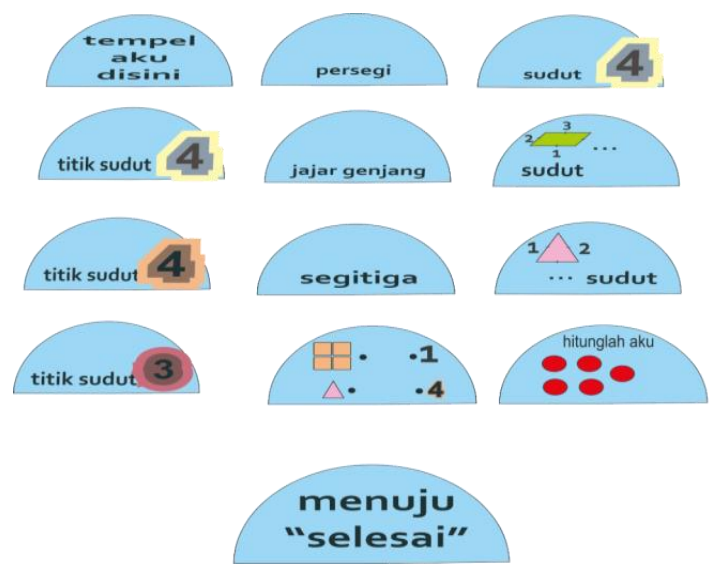

Gambar 6. Desain Buku Art Paper 
Buku art paper ini merupakan soal-soal mengenai pembahasan berpikir simbolik. Pada buku geometri anak mengambil berbagai macam benda dalam bentuk gambar dan tulisan untuk ditempel di batok kelapa kemudian anak mencocokkan gambar dan tulisan pada geometri setengah lingkaran. Pada alat batok kelapa ini memiliki ukuran sesuai dengan buah kelapa dan panjang tali berukuran $40 \mathrm{~cm}$.

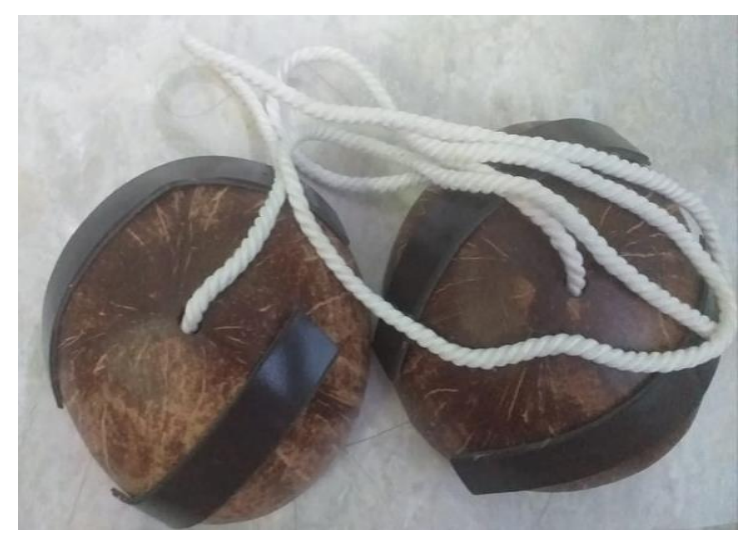

Gambar 7. Alat Batok Kelapa

Tahap desain juga terdapat penyusunan instrumen angket ahli media dan ahli materi, lembar pengamatan yang dibuat dalam bentuk google form. Angket ahli media dan ahli materi ini menunjukkan kelayakan media tempel aku, angket ini berisi kesesuaian, kemenarikan, kepraktisan, keamanan, dan tingkat pencapaian perkembangan anak. Selain itu dilakukan juga uji coba pengguna untuk anak usia dini 5-6 tahun dan dimasukkan kedalam lembar pengamatan yang diisi oleh 10 orang guru PAUD digunakan untuk memberikan informasi penting mengenai penggunaan media.

\section{Development (Pengembangan)}

Tahap pengembangan meliputi perancangan prototype pembuatan alas dengan menggunakan corel draw berupa rancangan media Tempel Aku dengan tahapan formatif. Pengembangan media tempel aku ini adalah pengembangan yang mengembangkan aspek kognitif berfikir simbolik untuk anak usia 5-6 tahun. Pengembangan media Tempel Aku sesuai dengan tahap desain yang berisi langkahlangkah, bentuk geometri, buku Tempel Aku, dan batok kelapa. Protytpe terbuat dari bahan banner dengan bahan vinly untuk alasnya dan buku geometri dari kertas art paper.

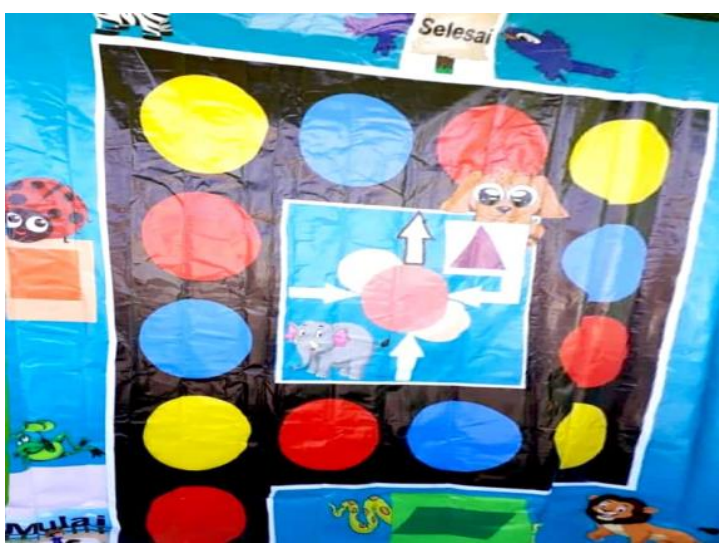

Gambar 8. Alas Media Tempel Aku
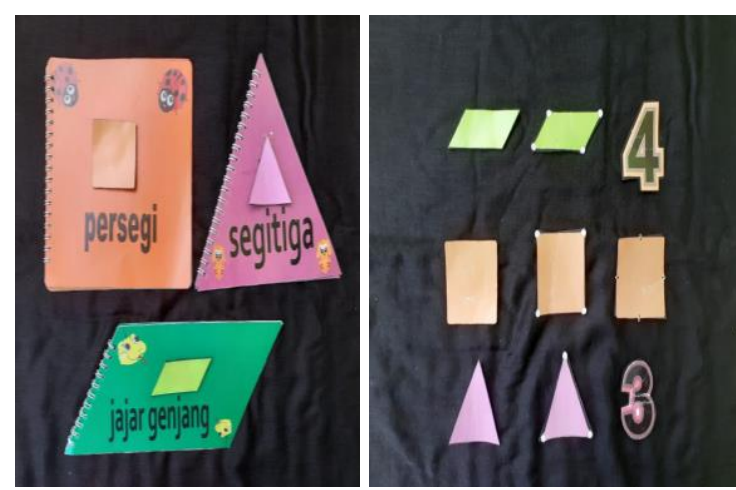

Gambar 9. Buku Geometri
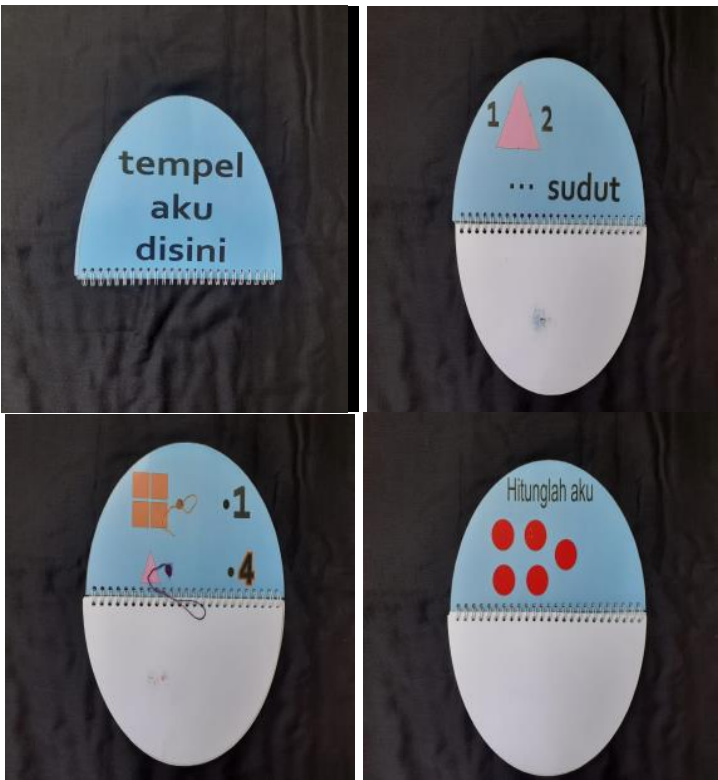

Gambar 10. Buku Tempel Aku

Buku panduan yang berisi panduan penggunaan media yaitu (1) anak dapat menyusun geometri dengan benar; (2) dapat dimainkan oleh 1 orang anak dengan usia 5-6 tahun; (3) cara bermain: siapkan banner, siapkan batok kelapa dan petunjuk, setelah selesai disiapkan letakkan diatas tulisan mulai, media Tempel Aku siap dimainkan. 
Cara bermain atau petunjuk bermain pada Tempel Aku dengan meningkatkan berpikir simbolik dengan tata cara: (1) ambilah batok kelapa; (2) pasangkan batok kelapa ditengah jari jempol dan jari telunjuk pada kaki; (3) menujulah ke geometri jajar genjang; (4) buka buku dan ambil bagian yang bisa ditempel; (5) temukan petunjuk selanjutnya; (6) seteleh selesai menemukan pasangan di tiga geometri pasangkan ke geometri setengah lingkaran.

Tahapan selanjutnya yakni setelah melalui tahap merancang kemudian produk akan divalidasi oleh ahli media dan ahli materi dengan saran dan komentar menurut ahli media aspek yang dinilai dalam media adalah pemilihan bahan, kemenarikan, kerapian dan pemilihan warna. Menurut ahli materi aspek yang dinilai adalah perkembangan kognitif berfikir simbolik anak usia 5-6 tahun validasi ini dilakukan untuk mengetahui kevalidan dan kelayakan produk media Tempel Aku yang telah dikembangkan. Penilaian ini dilakukan oleh satu orang ahli dengan mengirimkan angket berupa google form. Pembutan angket ahli media berisi tentang kemenarikan, kesesuaian, kepraktisan, dan keamanan. Angket ahli materi berisi tentang indikator materi dalam meningkatkan berpikir simbolik, kelayakan media. Angket ini bertujuan memberikan penilaian tentang kevalidan media Tempel Aku untuk dikembangkan.

Tabel 5. Hasil Validasi Media

\begin{tabular}{|c|c|}
\hline Aspek yang Dinilai & $\begin{array}{l}\text { Sk } \\
\text { or }\end{array}$ \\
\hline $\begin{array}{l}\text { Kesesuaian pemilihan pada alas } \\
\text { menggunakan bahan Vinly }\end{array}$ & 4 \\
\hline $\begin{array}{llc}\text { 2. } & \begin{array}{l}\text { Kesesuaian pemilihan alat } \\
\text { menggunakan batok kelapa }\end{array} & \\
\end{array}$ & 4 \\
\hline $\begin{array}{l}\text { Kesesuaian pemilihan kartu } \\
\text { geometri menggunakan art paper }\end{array}$ & 4 \\
\hline $\begin{array}{l}\text { Kemenarikan kombinasi } \\
\text { pada media Tempel Aku }\end{array}$ & 4 \\
\hline $\begin{array}{l}\text { 5. Kemenarikan desain pada media } \\
\text { tempel aku }\end{array}$ & 4 \\
\hline $\begin{array}{l}\text { 6. Kepraktisan alat dan bahan media } \\
\text { (mudah disimpan dan dipindahkan) }\end{array}$ & 5 \\
\hline $\begin{array}{l}\text { 7. Keamanan alat dan bahan dalam } \\
\text { media pembelajaran aman untuk } \\
\text { anak }\end{array}$ & 5 \\
\hline $\begin{array}{l}\text { 8. Keamanan ukuran tulisan pada } \\
\text { kartu geometri terlihat jelas dan } \\
\text { sesuai untuk anak }\end{array}$ & 4 \\
\hline Nilai total & 34 \\
\hline
\end{tabular}

Berdasarkan hasil validasi media yang telah dilakukan oleh ahli media, diperoleh skor 34 dengan perhitungan berikut:

$\mathrm{P}=\frac{34}{40} \times 100=85 \%$

Hasil perhitungan tersebut maka didapat nilai kevalidan media sebesar $85 \%$ untuk menujukkan bahwa media yang digunakan dalam media Tempel Aku memenuhi kriteria. Berdasarkan hasil tersebut, maka dapat disimpulkan bahwa kemampuan kognitif berpikir simbolik usia 5-6 tahun valid atau layak digunakan tanpa revisi.

Tabel 6. Hasil Validasi Materi

\begin{tabular}{|c|c|c|}
\hline $\begin{array}{l}\mathbf{N} \\
\mathbf{0}\end{array}$ & Aspek yang Dinilai & $\begin{array}{l}\text { Sk } \\
\text { or }\end{array}$ \\
\hline 1. & $\begin{array}{l}\text { Dapatkah media tempel aku dapat } \\
\text { meningkatkan } \\
\text { berpikir simbolik }\end{array}$ & 4 \\
\hline
\end{tabular}

2. Materi pembelajaran Tempel Aku 4 mampu menyebutkan lambang bilangan 1-5

3. Media Tempel Aku mampu 4 mencocokkan lambang bilangan yang sama

4. Media Tempel Aku mampu 5 membantu anak mencocokan bentuk-bentuk geometri (jajar genjang, persegi, segitiga)

5. Media Tempel Aku mampu 4 mengurutkan bentuk geometri

6. Media Tempel Aku mampu 4 mengidentifikasi dalam bentuk gambar atau tulisan pada geometri

\begin{tabular}{llcrc}
\hline 7. & $\begin{array}{l}\text { Materi media } \\
\text { berhubungan } \\
\text { pembelajaran }\end{array}$ & $\begin{array}{c}\text { Tempel } \\
\text { dengan }\end{array}$ & $\begin{array}{r}\text { Aku } \\
\text { tema }\end{array}$ & 3 \\
\hline
\end{tabular}

8. Penyajian media Tempel Aku 4 mendukung anak terlibat dalam bermain

9. Permainan media Tempel Aku 4 dapat menjadi bahan referensi bagi guru untuk menghadirkan permainan dalam pembelajaran disekolah

10. Pengembangan media Tempel Aku 3 merupakan permainan yang tidak membosankan

$$
\text { Nilai total }
$$


Berdasarkan hasil validasi materi yang telah dilakukan oleh ahli materi, diperoleh skor 39 dengan perhitungan berikut:

$\mathrm{P}=\frac{39}{50} \times 100=78 \%$

Hasil nilai kevalidan materi sebesar $78 \%$ yang menujukkan bahwa materi yang digunakan dalam media Tempel Aku memenuhi kriteria. Berdasarkan hasil tersebut, maka dapat disimpulkan bahwa kemampuan kognitif berpikir simbolik usia 5-6 tahun valid atau layak digunakan tanpa revisi. Melalui hasil validasi didapatkan saran dari ahli materi dan ahli media dengan saran memperbaiki skala pada instrument validasi materi. Berdasarkan validasi yang dilakukan, maka media Tempel Aku dinyatakan valid. Setelah media Tempel Aku dinyatakan valid maka media siap digunakan dalam uji coba penelitian.

Pada tahap uji coba pengguna menggunakan lembar pengamatan divalidasi oleh akademisi dengan saran dan komentar menggunakan lembar pengamatan bukan angket karna angket digunakan yang bersangkutan atau mengalami langsung, kemudian untuk aspek yang dinilai disesuaikan dengan perkembangan kognitif berpikir simbolik usia 5-6 tahun. Setelah melakukan validasi dilakukan tahap uji coba dengan uji coba terbatas yang menggunakan anak usia dini berumur 5-6 tahun dan berjumlah 5 orang anak. Pertama anak akan diajak untuk bermain media Tempel Aku dan dipanggil satu persatu, kemudian anak tersebut membaca langkah-langkah, setelah membaca langkah-langkah anak memasangkan batok kelapa dan berjalan di geometri yang sudah ditentukan. Uji coba tersebut ada satu anak yang mengalami ketakutan karna anak belum bisa memakai batok kelapa kemudian anak tersebut melihat teman-temanya dan akhirnya dia mau berusaha, kemudian ada 3 orang anak yang mengatakan mudah dan seru, dan 1 orang anak yang malu-malu tetapi bisa melakukannya. Uji coba kepada 5 orang anak ini dilakukan untuk melihat kelayakan media. Uji coba tersebut direkam dalam bentuk video kemudian dimasukkan dalam bentuk google form dengan menggunakan lembar pengamatan untuk 10 guru PAUD dan dibagikan melalui kuisoner. Pada pelaksanaan uji coba ini dilakukan untuk mengetahui kelayakan dan keparaktisan desain yang dilakukan secara terbatas tanpa dilakukan proses pembelajaran yang sebenarnya yaitu di TK. Pada tahap pengamatan, guru mengisi angket dengan memberikan tanda checklist $(\sqrt{ })$ pada pernyataan yang dianggap sesuai. Data tersebut kemudian dihitung dengan menggunakan rumus data hasil responden. Berikut merupakan hasil dari lembar pengamatan guru PAUD.

Tabel 7. Lembar Pengamatan

\begin{tabular}{|c|c|c|c|}
\hline \multirow[t]{2}{*}{ Pernyataan } & \multicolumn{2}{|c|}{ Respon } & \multirow{2}{*}{$\begin{array}{l}\text { Sk } \\
\text { or }\end{array}$} \\
\hline & Ya & Tidak & \\
\hline $\begin{array}{l}\text { Apakah media Tempel Aku } \\
\text { mudah digunakan oleh anak }\end{array}$ & 9 & 1 & 9 \\
\hline $\begin{array}{l}\text { Apakah bentuk tampilan } \\
\text { media Tempel Aku menarik } \\
\text { bagi anak }\end{array}$ & 9 & 1 & 9 \\
\hline $\begin{array}{l}\text { Apakah petunjuk dalam media } \\
\text { Tempel Aku sudah jelas }\end{array}$ & 6 & 4 & 6 \\
\hline $\begin{array}{l}\text { Apakah jenis } \text { ukuran dan } \\
\text { tulisan pada media sesuai } \\
\text { dengan anak }\end{array}$ & 9 & 1 & 9 \\
\hline $\begin{array}{lr}\text { Dapatkah media Tempel Aku } \\
\text { mampu } & \text { meningkatkan } \\
\text { perkembangan } & \text { berpikir } \\
\text { simbolik anak usia 5-6 tahun }\end{array}$ & 10 & 0 & $\begin{array}{l}1 \\
0\end{array}$ \\
\hline 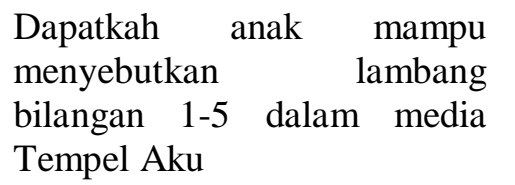 & 10 & 0 & 10 \\
\hline $\begin{array}{lr}\text { Apakah media } & \text { Tempel Aku } \\
\text { mampu } & \text { memberikan } \\
\text { pembelajaran } & \text { bentuk-bentuk } \\
\text { geometri } & \text { (jajargenjang, } \\
\text { persegi,segitiga) }\end{array}$ & 10 & 0 & 10 \\
\hline $\begin{array}{l}\text { Dapatkah anak memasangkan } \\
\text { dan membedakan bentuk } \\
\text { gambar tulisan dalam media } \\
\text { Tempel Aku }\end{array}$ & 9 & 1 & 9 \\
\hline $\begin{array}{l}\text { Apakah media Tempel Aku } \\
\text { dapat mendukung anak terlibat } \\
\text { dalam bermain }\end{array}$ & 10 & 0 & 10 \\
\hline $\begin{array}{l}\text { Apakah media Tempel Aku } \\
\text { dapat menjadi referensi bagi } \\
\text { guru untuk menghadirkan } \\
\text { permainan } \\
\text { pembelajaran disekolah dalam } \\
\end{array}$ & 9 & 1 & 9 \\
\hline $\begin{array}{l}\text { Apakah pengembangan media } \\
\text { Tempel Aku merupakan } \\
\text { permainan yang tidak } \\
\text { membosankan }\end{array}$ & 7 & 3 & 7 \\
\hline Nilai Total & & 98 & \\
\hline $\begin{array}{l}\text { Berdasarkan hasil lemba } \\
\text { yang dilakukan oleh } 10 \\
\text { menunjukkan bahwa nilai total } \\
\text { penjumlahan yang menjawab }\end{array}$ & & $\begin{array}{l}n \\
\ln g a m a \\
\lg \quad g\end{array}$ & \\
\hline
\end{tabular}


dengan perolehan skor sebesar 98 dan perhitungan sebagai berikut:

$\mathrm{P}=\frac{98}{110} \times 100 \%=89 \%$

Hasil lembar pengamatan media sebesar 89\% yang menujukkan bahwa media Tempel $\mathrm{Aku}$ dalam meningkatkan kemampuan kemampuan kognitif berpikir simbolik anak usia 5-6 tahun termasuk dalam kategori sangat praktis. Berdasarkan hasil tersebut didapatkan saran dan komentar dari guru PAUD bahwa media tempel aku merupakan permainan yang menyenangkan dan tidak membosankan bagi anak usia dini, tidak sulit sebenarnya tapi terlalu rumit, sangat menginspirasi.

Selama proses uji coba produk diketahui bahwa anak-anak sangat bersemangat dan antusias dengan adanya media Tempel Aku sebagai sarana belajar. Kegiatan pembelajaran berlangsung aktif terutama pada saat kegiatan memainkan batok kelapa hal tersebut dapat dilihat pada Tabel 6 dengan hasil lembar pengamatan pada butir 2 yang menjelaskan bahwa bentuk tampilan media menarik bagi anak dengan hasil skor 9. Hasil dari pernyataan pada butir 1 juga menjelaskan bahwa media Tempel Aku mudah digunakan oleh anak dengan hasil skor 9. Kemudian hasil tersebut diperkuat juga dengan hasil lembar pengamatan pada butir 5 yang menjelaskan bahwa media Tempel Aku mampu meningkatkan kemampuan kognitif berpikir simbolik usia 5-6 tahun dengan hasil skor 10.

Adanya media permainan Tempel Aku mampu meningkatkan kemampuan kognitif dalam berpikir simbolik yang mempunyai beberapa tingkat pencapaian perkembangan anak salah satunya dapat dilihat pada Tabel 6 dengan hasil lembar pengamatan pada butir 6 yang menjelaskan bahwa anak mampu menggunakan lambang bilangan untuk menghitung dengan skor 10. Hal tersebut sejalan dengan pendapat (Cahyani, 2020) yang mengatakan bahwa pengenalan lambang bilangan adalah salah satu kemampuan dalam aspek kognitif. Pengenalan lambang bilangan ini merupakan kemampuan dasar dalam pembelajaran matematika. Selain itu, pengenalan lambang bilangan dapat juga memengaruhi anak dalam kesiapan jenjang pendidikan selanjutnya.

Selanjutnya kemampuan kognitif tingkat pencapaian perkembangan anak dapat dilihat pada Tabel 6 dengan hasil lembar pengamatan pada butir 7 yang menjelaskan bahwa permainan media Tempel Aku mampu memberikan pembelajaran bentuk-bentuk geometri (jajar genjang, persegi, segitiga) dengan hasil skor 10. Menurut (Puspitasari, Kristanto, \& Khasanah, 2015) bahwa geometri adalah cabang matematika yang menjelaskan garis, sudut, bidang, sifat-sifat, bidang dan titik dalam ruang. Menurut (Prasetya, 2015) mengatakan geometri adalah kemampuan anak-anak mengenal bentuk, mengetahui bangunan, dan menyebutkan gambar seperti lingkaran, segiempat, segitiga. Pada media geometri ini bahan yang digunakan adalah kertas art paper yang diletakkan dialas banner dan dikasih perekat untuk menempelkan dibatok kelapa. Adapun cara bermain sebagai berikut: Ambilah batok kelapa, pasangkan batok kelapa ditengah jari jempol dan jari telunjuk pada kaki, menujulah ke geometri jajar genjang, buka buku dan ambil bagian yang bisa ditempel, temukan petunjuk selanjutnya, seteleh selesai menemukan pasangan di tiga geometri pasangkan ke geometri setengah lingkaran. Dengan demikian penerapan pembelajaran media Tempel Aku dapat meningkatkan kemampuan kognitif pada anak usia 5-6 tahun.

Hal lain dari tingkat pencapaian perkembangan anak dapat dilihat pada Tabel 6 dengan hasil lembar pengamatan pernyataan pada butir 3 yang menjelaskan bahwa petunjuk dalam Tempel Aku sudah jelas dengan hasil skor 6 , dan juga penyataan pada butir 4 yang menjelaskan bahwa ukuran dan tulisan sesuai dengan anak dengan hasil skor 9. Selanjutnya lembar pengamatan pada butir 8 yang menjelaskan bahwa anak dapat memasangkan dan membedakan bentuk gambar dan tulisan dalam permainan media tempel aku dengan hasil skor 9 , untuk pernyataan pada butir 9 media Tempel Aku dapat mendukung anak terlibat dalam bermain dengan hasil skor 10, untuk hasil lembar pengamatan pada butir 10 menjelaskan bahwa media Tempel Aku dapat menjadi bahan referensi bagi guru untuk menghadirkan permainan dalam pembelajaran disekolah dengan hasil skor 9, dan untuk pernyataan butir 11 media Tempel Aku merupakan permainan yang tidak membosankan dapat dilihat dengan hasil skor 7. Berdasarkan hal tersebut media Tempel Aku adalah permainan yang mendukung anak dalam mengembangkan perkembangan kognitif berpikir simbolik yang dapat menghubungkan dengan permainan tradisional.

Penelitian ini didukung oleh hasil penelitian (Dewi, Adnyana, \& Suardika, 2014) yang menyatakan bahwa penerapan 
pembelajaran konteksual bernuansa bermain dengan bantuan media geometri dapat meningkatkan kemampuan kognitif dalam penggunaan lambang bilangan dan pengenalan konsep pada anak kelompok B di TK Erawan Jagapati Abiansemal Bandung tahun ajaran 2013/2014. Berdasarkan hasil penelitian dari uraian tersebut, maka persamaan dengan penelitian media Tempel Aku adalah menggunakan bantuan geometri sebagai alat bermain anak yang dapat meningkatkan kemampuan kognitif berpikir simbolik anak usia 5-6 tahun.

Menurut Piaget, teori perkembangan kecerdasan kognitif memfokuskan pada ingatan anak, kepercayaan anak dan persepsi anak. Teori perkembangan kognitif menurut Piaget juga mengatakan teori anak yang bisa beradaptasi dengan cara menginterpresentasikan pada objek dan kejadian-kejadian yang ada di sekitarnya (Sit, 2017). Teori ini juga menjelaskan perkembangan kognitif adalah pusat perkembangan organisme. Keadaan ini merujuk pada pendapat Piaget yang mengatakan ada dua kecerdasan yaitu kecerdasan operatif, kecerdasan ini berkaitan dengan tindakan, aturan, perbaikan, perubahan objek, dan minat seseorang. Kedua kecerdasan figuratif, kecerdasan ini lebih banyak menggunakan representasi guna mempertahankan penyataan seperti bentuk, lokasi, dan bentuk yang berurutan. Piaget mengatakan bahwa perubahan kedua kecerdasan ini disebut asimilasi dan akomodasi.

Berdasarkan hal ini maka perkembangan kemampuan kognitif dapat disimpulkan bahwa permainan media Tempel Aku terhadap kemampuan berpikir simbolik dapat dikembangkan untuk anak usia 5-6 tahun. Hal ini sejalan dengan (Nurtaniawati, 2017) menjelaskan perkembangan kognitif adalah perkembangan yang dapat membantu anak dalam mengembangkan kemampuan logika matematika, yang dapat menemukan macammacam pemecahan masalah, mengolah proses belajar, mempelajari pengetahuan akan ruang dan waktu dan mempunyai kemampuan berpikir secara teliti. Penelitian selanjutnya adalah (Juniarti, Arofah, \& Azizah, 2018) menyatakan kognitif ialah pengetahuan yang memiliki daya nalar sangat luas, kreativitas yang bagus serta kemampuan berbahasa dan daya ingat yang berkembang. Pendapat tersebut diperkuat oleh (Hardiyanti, Sasmiati, \& Sabdaningtyas, 2018) bahwa kemampuan kognitif berpikir simbolik adalah kemampuan anak menggunakan simbol- simbol pada tahap ini kemampuan berpikir simbolik pada anak usia 5-6 tahun termasuk dalam tahap belajar mengenal lambang bilangan.

\section{Implementation (Pelaksanaan)}

Tahap implementasi dilakukan dengan tahap sumatif untuk menguji keefektifan. Namun tidak bisa bisa dilakukan karena keadaan dan akan dilakukan pada peneliti selanjutnya.

\section{Evaluation (Evaluasi)}

Tahap akhir yaitu evaluasi dari media tempel aku dalam meningkatkan perkembangan kognitif berpikir simbolik usia 5-6 tahun. Evaluasi yang dilakukan adalah evaluasi hasil pengumpulan data dan informasi dengan tahap wawancara guru TK untuk menemukan permasalahan yang terjadi pada anak dan menemukan solusi untuk permasalahan tersebut. Evaluasi yang dilakukan pada tahap desain agar dapat dikembangkan media untuk membantu permasalahan anak. Evaluasi pengembangan dilakukan oleh ahli media, ahli materi, dan uji pengguna, yakni saran dan masukan dari ahli media dan materi memperbaiki skala pada instrumen validasi materi didapatkan saran dan masukkan dari uji coba pengguna adalah dapat membantu guru dalam mengajar, sangat menginspirasi, penyampaian lebih diperjelas, tidak sulit sebenernya tapi terlalu rumit bagi anak TK. Evaluasi tahap implementasi tidak bisa dilakukan dan akan dilakukan pada peneliti selanjutnya.

\section{KESIMPULAN DAN SARAN Kesimpulan}

Hasil penelitian pengembangan ini dapat disimpulkan bahwa telah menghasilkan desain media Tempel Aku yang dinyatakan layak untuk digunakan. Hasil validasi dari ahli media memperoleh nilai sebesar $85 \%$ dengan kategori valid, hasil ahli materi sebesar $78 \%$ dengan kategori valid dan lembar pengamatan untuk 10 orang guru adalah $89 \%$ dengan kategori sangat praktis. Berdasarkan hasil validasi ahli media, materi, dan lembar pengamatan dinyatakan layak untuk media Tempel Aku dalam meningkatkan kemampuan kognitif berpikir simbolik usia 5-6 tahun.

\section{Saran}

Berdasarkan hasil penelitian dan pengembangan yang telah dilakukan, maka diberikan saran sebagai berikut: (1) bagi sekolah, diharapkan dapat menjadi referensi dalam mengaplikasikan media dan dapat diterapkan disekolah sebagai permainan menarik dan menyenangkan; (2) bagi guru, diharapkan 
bisa digunakan sebagai pedoman dalam pembelajaran dan sebagai acuan permainan yang menyenangkan dan kreatif bagi anak; (3) bagi peneliti selanjutnya, diharapkan dapat dikembangakan untuk memaksimalkan perkembangan kognitif berpikir simbolik anak usia 5-6 tahun.

\section{DAFTAR PUSTAKA}

Aprilianti, R. M., \& Fitri, R. (2019). Pengaruh Permainan "Ikuti Jejakku" Terhadap Kemampuan Mengenal Lambang Bilangan Pada Anak Kelompok B Di Tk Dharma Wanita Punggul Sidoarjo. Jurnal PAUD Teratai, 8(3), 1-6.

Cahyani, A. D. N. (2020). Meningkatkan Kemampuan Mengenal Lambang Bilangan Pada Anak Usia 4-5 Tahun Melalui Permainan Balok Angka. Jurnal Pendidikan Anak Usia Dini Undiksha, 8 (3), 181-190.

Dewi, P. K., \& Nia, B. (2018). Media Pembelajaran Bahasa: Aplikasi Teori Belajar dan Strategi Pembelajaran. Malang: UB Press.

Dewi, S. B. K., Adnyana, \& Suardika, R. (2014). Penerapan Pembelajaran Kontekstual Bernuansa Bermain Berbantuan Media Geometri Untuk Meningkatkan Kemampuan Kognitif Anak. Jurnal Pendidikan Anak Usia Dini Undiksha, 2(1), 1-11.

Fitri, W. O., \& Ibrahim, H. (2019). Meningkatkan Kemampuan Visual Spasial Melalui Kegiatan Bermain Bongkar Pasang Puzzle Logika. Jurnal Riset Golden Age PAUD UHO, 2(1), 70-76.

Hamidah, A. (2020). Pengembangan Buku Panduan Teka Teki Silang Pada Pemecahan Masalah Anak Kelompok B. Jurnal PAUD Teratai, 9(1), 51-52.

Hamid, M, A. (2020). Media pembelajaran. Medan: Yayasan Kita Menulis.

Hardiyanti, L., Sasmiati, \& Sabdaningtyas, L. (2018). Penggunaan Media Dan Kemampuan Berfikir Simbolik Anak Usia Dini. Jurnal Pendidikan Anak FKIP Universitas Lampung, 4(1).

Islamiyah, R., Setiawati, F. A., \& Utami, W. S. (2020). Computer-based "Color-Mixing Maze Game" to stimulate symbolic thought for the development of learning science in early childhood. Journal of physics: conferences series, 1511 012112.

Jalinus, N., \& Ambiyar. (2016). Media dan Sumber Pembelajaran. Jakarta: Kencana

Juniarti, F., Arofah, N. D., \& Azizah, S. R. (2018). Meningkatkan Percaya Diri Anak Pada Aspek Kognitif Dengan MetodeBercerita. Jurnal Tunas Siliwangi, 4(1), 32-37.

Kartika, D., \& Fitri, R. (2018). Efektivitas Kegiatan Menggambar Terhadap Kemampuan Kognitif Mengenal Warna Primer Pada Anak Kelompok A Di TK Gotong Royong Kecamatan Genteng Surabaya. Jurnal PAUD Teratai, 7(3), $1-5$.

Kustandi, C., \& Darmawan, D. (2020). Pengembangan Media Pembelajaran. Kencana: Divisi prenadamedia group.

Lestari, P. I., \& Prima, E. (2019). Balinese CongklakGames, Maciwa, to Improve the Development of Symbolic Thinking in Early Childhood. Jurnal Obsesi: Jurnal Pendidikan Anak Usia Dini, 3 (1), 103-104.

Malichah, L., \& Rakhmawati, N. I. K. (2018). Modifikasi Permainan Engklek Terhadap Kemampuan Mengenal Bentuk Geometri Pada Anak Usia 5-6 Tahun. Jurnal PAUD Teratai, 7(2), 1-9.

Mashuri, S. (2019). Media Pembelajaran Matematika. Yogyakarta: Deepublish.

Mertayasa, I, W., \& Sudarsana, I. K. (2018). Pendidikan Karakter Pada Anak Usia Dini. Bali: Jayapangus Press.

Mufarrohah, L., \& Rukmi, A. S. (2020). Pengembangan Media Video Animasi Dua Dimensi Untuk Keterampilan Menulis Puisi Siswa Kelas IV Sekolah Dasar. Jurnal Penelitian Pendidikan Guru Sekolah Dasar, 8(5), 861-871.

Narni, \& Salwiah. (2020). Meningkatkan Kemampuan Kognitif Anak Melalui Kegiatan Mencocokkan Gambar. Jurnal Riset Golden Age PAUD UHO, 3(1), 35-43. 
Ningrum, M. A., \& Chusna, L. A. (2020). Inovasi Dakon Geometri Dalam Menstimulasi Kemampuan Mengenal Bentuk Geometri Anak Usia Dini. Kwangsan: Jurnal Teknologi Pendidikan, 8(1), 20-21.

Nurtaniawati. (2017). Peran Guru Dan Media Pembelajaran Dalam Menstimulasi Perkembangan Kognitif Pada Anak Usia Dini. Jurnal Tunas Siliwangi, 3(1), 120.

Prasetya, I. A. (2015). Upaya Meningkatkan Pengenalan Bentuk Geometri Dengan Metode Demonstrasi Kelompok A Paud Bina Ceria Semarang. PAUDIA: Jurnal Penelitian dalam Bidang Pendidikan Anak Usia Dini, 4(1), 83-84.

Puspitasari, D. P., Kristanto, M., \& Khasanah, I. (2017). Peningkatan Kreativitas Seni Kolase Melalui Keping Geometri Pada Kelompok B Tk Aisyiyah Busthanul Athfal 34 Semarang Tahun Ajaran 2016/2017. PAUDIA: Jurnal Penelitian dalam Bidang Pendidikan Anak Usia Dini, 6 (2), 11-26. https://doi.org/10.26877/paudia.v6i2.21 01

Setyosari, P. (2020). Desain Pembelajaran. Jakarta Timur: PT Bumi Aksara.

Sholihah, I., \& Rakhmawati, N. I. S. (2019). Pengaruh Permainan Tradisional Ular Naga Modifikasi Terhadap Aspek Perkembangan Kemampuan Berhitung Anak Usia 5-6 Tahun. Jurnal PAUD Teratai, 8(1), 1-7.

Sit, M. (2017). Psikologi Perkembangan Anak. Jakarta: Kencana.

Swaboda, N., Meder, B., \& Ruggeri, A. (2020). Finding the (most efficient) way out of a maze is easier than asking (good) questions.

https://doi.org/10.31234/osf.io/tdaqg

Thobroni, M., \& Mumtaz, F. (2011). Mendongkrak kecerdasan anak melalui bermain dan permainan. Yogyakarta: Katahati.

Ulandari, S., Hukmi, \& Febrialismanto. (2020). Pengembangan Media Pembelajaran Maze Trap Game Untuk Meningkatkan Kemampuan Motorik Halus Anak Usia 5-6 Tahun Di Tk Islam As-Shofa Kota
Pekanbaru. Jurnal Review Pendidikan dan Pengajaran, 3(2), 367-374. https://doi.org/10.31004/jrpp.v3i2.1371

Wahdini, R., \& Fitri, R. (2017). Meningkatkan Kemampuan Kognitif Mengenal Warna Primer Melalui Kegiatan Mewarnai dengan Kapas Pada Anak Kelompok B. Jurnal PAUD Teratai, 6(1), 1-4. 